\title{
The Bauhaus Pots and Cups Express the Spirit of the Twentieth Century: Design in Art History and Pevsner's Definition of the Modern Movement
}

\author{
Rebeka Vidrih* \\ University of Ljubljana, Eslovenia
}

\begin{abstract}
Nikolaus Pevsner's Pioneers of Modern Movement is considered the foundational text of two new historical fields, the history of modern architecture and the history of design. This contribution, nevertheless, discusses this text in the context of art-historical discipline. Pevsner himself namely understood his work as a complement to Kunstgeschichte: by defining the 'Modern Movement' in established art-historical terms and also by discussing not only architecture but attempting to define the style and the worldview expressed in it for the whole period and all of visual arts. Specifically, this contribution is interested in the place that Pevsner allocated to the design within his art-historical edifice, since inclusion of objects of everyday use within an art-historical study was not (and still is not) usual. For Pevsner, on the contrary, design (linked to architecture) turns out to be a key component of his narrative, even if not for aesthetic but rather for moral or social reasons.
\end{abstract}

Keywords: Nikolaus Pevsner, history of design, history of modern architecture, the Modern Movement, Herbert Read, Alois Riegl. 
Nikolaus Pevsner's Pioneers of Modern Movement (1936; or, as the title was changed in the next edition, of Modern Design) is considered to be the foundational text for shaping of two new historical fields, the text founding two new histories: the history of modern architecture and the history of design ${ }^{1}$. He consciously and decisively participated in the former endeavour, but probably quite accidentally in the latter. Here, however, we are interested in this text in the context of the art-historical discipline. Pevsner himself understood his work as a contribution to the field of the established Kunstgeschichte, as developed in German-speaking countries in the second half of the nineteenth and in the first decades of the twentieth century ${ }^{2}$. The task he set himself was to write down the history of art of the latest, the modern age, and to write it upon the same principles that were used for analysing and studying other, older epochs in European art history. He then understood his art-historical task in a traditional sense: to figure out the specific characteristics that define the style of the age in question and to discern the worldview which is expressed by the style so defined ${ }^{3}$.

Pevsner therefore attempts to define 'the new style', 'the style of the twentieth century', as 'a genuine and independent style', 'the genuine and legitimate style of our century', that is, as a legitimate stylistic epoch 'in the procession which leads from the Romanesque and the Gothic to the Renaissance of Brunelleschi and Alberti and the Baroque of Borromini and Neumann", so concluding but in that way also continuing the great history of European art so far. The Modern Movement, especially in architecture, is thus for Pevsner characterised by 'the new simplicity and severity', by the 'cleanness, directness, and precision' of form, reflecting 'honesty and saneness', 'reason and functionalism', and expressing 'the faith in science and technology, in social science and rational planning' on the one hand, but also 'the romantic faith in speed and the roar of machines' on the other ${ }^{5}$. The Modern Movement is such and it should be such because it was born in 'a world of science and technology, of speed and danger, of hard struggles and no personal security', in a world of 'science, technology, 
mass locomotion, mass production and consumption, mass communication', for 'today nothing of vital energy and beauty can be created unless it be fit for its purpose, in harmony with the material and the process of production, clean, straightforward and simple'6. The Modern Movement of the world of science and technology could therefore find the 'genuine and complete expression in unadorned shapes and surfaces' only, rather than in any kind of decoration?

The Pioneers of Modern Movement are a contribution to Kunstgeschichte by defining the 'Modern Movement' in established art-historical terms and also by discussing not only architecture but design and painting, too: Pevsner's art history is about defining the style and the worldview of the whole period in question, comprising all the visual arts. Even though architecture is consequently the primary field of investigation, the role of painting in Pevsner's story is also very important ${ }^{8}$. It was William Morris who broke with the academical tradition of classical architecture and who demanded art which would meet the demands of the new social circumstances, but his break with the tradition was not absolute, not yet complete. On the contrary, he 'dreamed of a revival of medieval society, medieval craft, and medieval forms', whereas only the painters of the last decade of the nineteenth century were those who 'fought for something that had never existed before', who searched for a style wholly 'free from period revival, unencumbered and uncompromising' ${ }^{9}$. The postimpressionist and symbolist painters were first to achieve 'the deliberate break with tradition', in the field of painting, which was performed only somewhat later by the Art Nouveau architects in the field of architecture as well ${ }^{10}$. The painters cleared the way and prepared the stage first and made the eventual arrival of Modern Movement, in architecture and in design, possible at all.

In defining the Modern Movement, the first and foremost question Pevsner is involved with is the question of how this new style of the new century was formed and developed: how and why it came to be as it was; what were the conditions, the reasons for its development - just as, for example, 
Alois Riegl was interested in Die Entstehung der Barockkunst in Rom (1908) how the Baroque art was developed out of the Renaissance conditions, how the Renaissance style was transformed into the Baroque; and only Heinrich Wölfflin with his Kunstgeschichtliche Grundbegriffe (1915) canonised these two styles into two clearly distinguished and contrasted stylistic units ${ }^{11}$. Pevsner is focused on how the Modern Movement came into being, what were its roots, its sources. Primarily interested in the pioneers, not the classics, he pursues 'three principal lines of progress' which ultimately lead to a synthesis in the style of the twentieth century ${ }^{12}$. The Modern Movement had, in his opinion, three essential sources: William Morris with the Arts and Crafts movement, who established the field of the creative activity, namely, domestic architecture and objects for everyday use; Art Nouveau, which broke with the academical tradition in decoration; and engineering architecture with its new materials and new mode of production ${ }^{13}$. These three lines of progression, concerning first the new problems, second, the new forms, and third, the new materials and processes, finally merged by the beginning of the First World War, in the activity of the leading architects of the younger generation who 'had courageously broken with the past and accepted the machine-age in all its implications' ${ }^{14}$.

Not much later, in his Outline of European Architecture (1942), Pevsner fastens the Modern Movement so defined to the long history of European art - focusing here, nevertheless, on architecture alone rather than on the entire field of visual arts -, confirming that the latest architecture is part and parcel of our cultural heritage, the legitimate stage in the development of the magnificent history of Western art.

\section{Design in Art History}

However, examining Pevsner's Pioneers in the context of the art-historical discipline, a glaring question imposes itself: how come design is such an important 
part of this story? Pevsner's inclusion of design in a basically kunstgeschichtliche text is surprising for at least two reasons. First, discussing objects of everyday use within an art-historical study was not usual, even though Alois Riegl, in the founding theoretical text of the art history, Historische Grammatik der bildenden Künste $(1966)^{15}$, did place 'industrial art (Kunstgewerbe)' alongside painting and sculpture and architecture as one of the four wings of the arthistorical edifice ${ }^{16}$. But he applied this structure of four parts in his study of Late Roman art only and did not employ it further, in his other studies of notable periods of art, the Renaissance and the Baroque, for example ${ }^{17}$. Other prominent art historians left out the objects for everyday use completely ${ }^{18}$. (Also, gradually and quietly architecture, too, slipped out of the art-historical purview, establishing history of architecture as a practically independent sub-discipline ${ }^{19}$.)

Second, Pevsner himself began his Outline with a loud and clear discrimination between the 'High Art' and the rest of the human artefacts: 'A bicycle shed is a building; Lincoln Cathedral is a piece of architecture' ${ }^{20}$. In his overview of European architecture, he actually considers 'pieces of architecture' alone; only with Morris 'design', too, appears as a part of the narrative, all of a sudden and unexplained ${ }^{21}$. In the Pioneers, too, Pevsner offers no explicit argument why is he discussing design at all ${ }^{22}$. He does not define the term and does not expound the concept. Moreover, he does not use the term 'design' consistently, but employs various expressions with more or less the same meaning - 'ornamentation', 'industrial art', 'machine art', 'architecture and decoration', 'the applied arts', 'industrial design' ${ }^{23}$ - thus blurring and even effacing the distinction between handicrafts and industrially produced objects, but also between decoration, ornamentation and design. Furthermore, he understands designing as an activity referred not only to the shaping of 'small things for everyday use' but to architectural planning as well ${ }^{24}$. Finally, in employing the syntagm 'industrial art' or 'machine art', elevation or exaltation of the objects for everyday use to the rank of Art is also presupposed. 
For this, Pevsner openly acknowledges his dependence on 'the most outstanding book on the subject'25, that is, Herbert Read's Art and Industry $(1934)^{26}$ in which, in Pevsner's words, 'the fundamental identity of the architect's and the designer's task in the Machine Age' is stressed ${ }^{27}$. In contradistinction to Pevsner's Pioneers, the main topic of Read's Art and Industry is design itself, but Read, too, an art historian like Pevsner, similarly considers design within a wider, basically art-historical context ${ }^{28}$. Whereas Pevsner is a champion of modern architecture, Read is a champion of modern art: he is interested in the place of design in the context of modern abstract painting and approaches the problem of 'the division existing between art and industry' ${ }^{29}$ from an art-historical position.

The solution to this problem lies not, in Read's opinion, in 'adapting machine production to the aesthetic standards of handicraft', but quite conversely in 'thinking out new aesthetic standards for new methods of production' ${ }^{30}$. He emphasises that a new aesthetic must be born out of "the solution of the immediate practical problems of the day', the first of which is 'the transformation of a million slum dwellings into cities of order, light, health and convenience' ${ }^{31}$. Discussing 'the general nature of art', Read distinguishes between 'two distinct types: humanistic art, which is concerned with the expression in plastic form of human ideals or emotions; and abstract art, or non-figurative art, which has no concern beyond making objects whose plastic form appeals to the aesthetic sensibility'32, that is, between figural images with a specific iconographical content and abstract images, addressing the viewer merely with their shapes and colours. His contention finally is 'that the utilitarian arts - that is to say, objects designed primary for use - appeal to the aesthetic sensibility as abstract art' ${ }^{\prime 3}$. Design, in Read's opinion, therefore belongs to the field of abstract art and he calls for 'a fuller recognition of the abstract artist in industry'34. Pevsner confirms all that in his turn, stating that 'there are no intrinsic distinctions of artistic rank between handicraft and machine art, though many distinction of kind' ${ }^{35}$. Nevertheless, in a way, it is not really necessary for Pevsner to argument the 
inclusion of design. William Morris and Walter Gropius, the beginning and the end of his narrative, were both active in both fields, in architecture and in design. Morris was primarily a designer and architect by association (with others), Gropius was primarily an architect, but he was also the visionary founder of the Bauhaus school. So it seems as if for Pevsner design simply came along with the activities of those two key personalities in the establishment of the Modern Movement.

But then again, when design is coupled with architecture, is considered one half of a team, one necessary half of 'the liaison of design and architecture' ${ }^{36}$, the reason for its inclusion ultimately is explicated, although not from an artistic or art-historical point of view. Pevsner's reason for the inclusion of design is not aesthetic but moral, or social. Morris is the beginner of 'a new era in Western Art' not so much because of the quality of his designs but because of his 'social conscience'37. Morris is 'the true prophet of the twentieth century' because 'we owe it to him that an ordinary man's dwelling-house has once more become a worthy object of architect's thought, and a chair, a wallpaper, or a

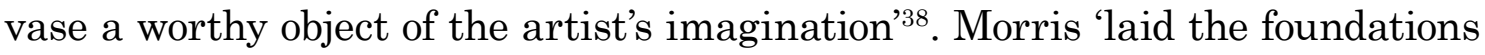
of the Modern Movement' not by the shapes of his designs but by 'indicting the contemporary architect's and artist's arrogant indifference to design for everyday needs' and by 'discrediting any art created by individual genius for a small group of connoisseurs ${ }^{39}$. Unfortunately, faced with the problem of the division existing between art and industry, Morris 'looked backward, not forward' in his 'pleading for handicraft', therefore 'the true pioneers of Modern Movement' can only be considered those who 'had gone further by discovering the immense, untried possibilities of machine $\operatorname{art}^{340}$. Morris laid the foundation of the modern style, but only with Gropius, with his embrace of industrial mode of production and of a specific aesthetics derived from it, its character was ultimately determined'41. Only with Gropius, the aesthetic consequences of the new economic and social circumstances were finally recognised and realised. 


\section{Social reason of the design in art history}

The architect's and the designer's interest in an ordinary human being, and their attention to his dwelling and his everyday surroundings characterise the essence of the Modern Movement. For, in Pevsner's opinion, a designer or an architect in the modern era 'is not a free artist': they both 'must believe in the moral value of serving - serving clearly defined purposes in their individual works, and serving the community in the whole of their activity ${ }^{92}$. The question of design is therefore 'a social question', and 'it is an integral part of the social question of our time'43. Namely, today, 'slum-clearance and re-housing are of the outmost importance', for they constitute an integral part of general 'social improvements ${ }^{\prime 4}$. The assurance of better living conditions for the everyman entails also the provision of appropriate housing. Since the modern era is an era of science and technology, of "mass locomotion, mass production and consumption, mass communication ${ }^{95}$, architects and designers should work and create in consideration to these conditions and requirements. 'A style of our age' should be 'an unexclusive style', and its merits should be 'collective merits, not distinguishing one individual or one class ${ }^{46}$. The modern style should be characterised 'by qualities which are essentially mass qualities'47. Pevsner contends that 'architecture and design for the masses must be functional', meaning 'that they must be acceptable to all and that their well-functioning is the primary necessity'48, and this is the reason, why 'the new style is bare', why 'it goes straight to the point" ${ }^{49}$, why the form of the modern buildings and of the modern objects is or should be simple, clean, direct, severe, and precise.

In this architect's and designer's interest and attention to the everyman's everyday surroundings, Pevsner also anchors his justification for his forceful declaration that the Modern Movement means 'aesthetic and social superiority'

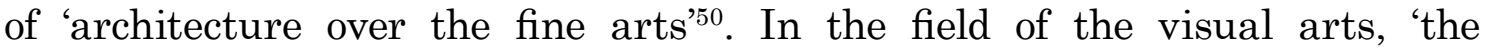
concentration on architecture and design for the masses and on what new 
materials and new techniques can do for them' guarantees 'the predominance of architecture and design over the beaux-arts ${ }^{51}$. For whereas 'architects and designers once more accepted social responsibilities' and 'architecture and design consequently became a service' - for 'buildings and objects of daily use were designed not only to satisfy the aesthetic wishes of their designers but also to fulfil their practical purposes fully and enthusiastically' -, 'painters and sculptors moved in exactly the opposite direction'52. The modern painters and sculptors, after they have broken with classical tradition at the end of the nineteenth century, remained preoccupied with formal and aesthetic problems alone. They retained and even strengthened their art-for-art'ssake attitude: their role in the Modern Movement therefore became only marginal and their importance in the further development of art diminished.

Even though Pevsner, in his Pioneers, did not clearly articulate and explicate its inclusion and its role, design in his narrative functions as a key component of an art-historical study. Far from being a mere supplement, an afterthought, 'a back wing', design - together with architecture - became the very carrier of artistic development. Design and architecture, because of their social dimension, constitute that part of the field of visual arts where the most pressing problems of the day are being solved and where therefore the preeminent expression of the contemporary times can be fashioned. Architecture and design are that part of the artistic field that for Pevsner - in 1930s, 1940s and still in 1960s - represents not only the present but also the future of visual arts. Not a Picasso's painting, but 'the Bauhaus pots and cups' express 'the spirit of the twentieth century'53. 


\section{NOTES}

1 Nikolaus Pevsner, Pioneers of Modern Design. From William Morris to Walter Gropius (Harmondsworth: Penguin, 1960, 3rd ed., revised and partly rewritten; first published in 1936 as Pioneers of Modern Movement). In establishing the history of modern architecture, Pevsner was not alone, other key contributors being Sigfried Giedion and Henry Russell Hitchcock; but in establishing the history of design, his paramount importance was never in doubt. See, for example: Panayotis Tournikiotis, The Historiography of Modern Architecture (Cambridge: The MIT Press, 1999); Alina Payne, "Pioneers of the Modern Movement from William Morris to Walter Gropius by Nikolaus Pevsner," Harvard Design Magazine, no. 16 (2002), 67; Gevork Hartoonian, The Mental Life of the Architectural Historian: Re-opening the Early Historiography of Modern Architecture (Newcastle upon Tyne: Cambridge Scholars Publishing, 2011); Clive Dilnot, "The State of Design History. Part I: Mapping the Field," Design Issues 1, no. 1 (1984), 8-9; Victor Margolin, "Design History or Design Studies: Subject Matter and Methods," Design Issues 11, no. 1 (1995), 5-7; Kjetil Fallan, Design History. Understanding Theory and Method (London: Bloomsbury, 2010), 2; John A. Walker, Design History and the History of Design (London: Pluto Press, 1989). Pevsner recapitulated and confirmed the findings of his Pioneers later in his Sources of Modern Architecture and Design (London: Thames and Hudson, 1968) and included them as a concluding stage of the history of architecture from the sixth to the twentieth century in his Outline of European Architecture (London: John Murray, 1948, 3rd ed.; first published in 1942). Only a year after the Pioneers, his Enquiry into Industrial Art in England (Cambridge: Cambridge University Press, 2010; first published in 1937) also appeared. Regarding the issue of design, it is usually held that the Pioneers provide a wider and a historical context for a more specific study of contemporary design alone in the Enquiry, but the texts can be read the other way round, too: the Enquiry providing the Pioneers with a more detailed argumentation for the relevance of design. The present contribution is focused on the analysing of the Pioneers but the other Pevsner's texts will also be referred to when necesarry or relevant. 2 Pevsner's body of work has not been thoroughly studied and evaluated yet in the context of art-historical scholarship. The foundations for that has been laid by these studies: Alina Payne, "Pioneers of the Modern Movement from William Morris to Walter Gropius by Nikolaus Pevsner," Harvard Design Magazine, no. 16 (2002), 66-70; Iain Boyd Whyte, "Nikolaus Pevsner: art history, nation, and exile," RIHA Journal 0075 (2013), 1-33, http://www.riha-journal.org/articles/2013/2013-oct-dec/ whyte-pevsner (accessed March 10, 2020); Emilie Oléron Evans, "Transposing the Zeitgeist? Nikolaus Pevsner between Kunstgeschichte and Art History," Journal of Art Historiography, no. 11 (2014), 1-18; Ute Engel, "The formation of Pevsner's art history: Nikolaus Pevsner in Germany 1902-1935," in Peter Draper (ed.), Reassessing Nikolaus Pevsner (London and New York: Routledge, 2017), 29-55; Stefan Muthesius, “Germannes, Englishness, Jewishness, scientificness, popularization?," in Peter Draper (ed.), Reassessing Nikolaus Pevsner (London and New York: Routledge, 2017), 57-69; and from a more biographical point of view: Stephen Games, Pevsner - The Early Life. Germany and Art (London: Continuum, 2010). About Pevsner's Pioneers, see: Colin Amery, “Nikolaus Pevsner's 'Pioneers of the Modern Movement', 1936," The Burlington 
Magazine 151, no. 1278 (2009), 617-619; Irene Sunwoo, "Whose Design? MoMA and Pevsner's Pioneers," Getty Research Journal, no. 2 (2010), 69-82; Ute Engel, “ "Fit for its purpose': Nikolaus Pevsner Argues for the Modern Movement," Journal of Design History 28, no. 1 (2014), 15-32; Rixt Hoekstra, "History in the Making: The Creation of Pevsner's Pioneers as Reconstructed from His Archives," Getty Research Journal, no. 8 (2016), 135-146. About Pevsner's Enquiry, see: Pauline Madge, "An Enquiry into Pevsner's Enquiry," Journal of Design History 1, no. 2 (1988), 113-126; Gillian Naylor, "Good design in British industry 1930-56," in Peter Draper (ed.), Reassessing Nikolaus Pevsner (London and New York: Routledge, 2017), 177-194. 3 'Architecture is not the product of materials and purposes - nor by the way of social conditions - but of the changing spirits of changing ages. It is the spirit of an age that pervades its social life, its religion, its scholarship and its arts. [...] The Modern Movement did not come into being because steelframe and reinforced-concrete construction had been worked out - they were worked out because a new spirit required them.' Pevsner, Outline, xxi. 4 Pevsner, Pioneers, 38, 147, 214; Pevsner, Outline, 215.

5 Pevsner, Pioneers, 17, 193, 202, 210; Pevsner, Enquiry, 112.

6 Pevsner, Pioneers, 217; Pevsner, Sources, 7; Pevsner, Enquiry, 10.

7 Pevsner, Enquiry, 19.

8 Sculpture, however, is hardly mentioned; Pevsner obviously does not consider its development as radical as that of painting; in a way design takes its place, design replaces sculpture as the three-dimensional creative activity. 9 Pevsner, Pioneers, 68.

10 Pevsner, Pioneers, 70, 148.

11 Alois Riegl, Die Entstehung der Barockkunst in Rom (Vienna: Anton Schroll, 1908); Heinrich Wölfflin, Kunstgeschichtliche Grundbegriffe. Das Problem der Stilentwicklung in der neueren Kunst (München: Hugo Bruckmann, 1917). 12 Pevsner, Pioneers, 147.

13 Pevsner, Pioneers, 118, 147.

14 Pevsner, Outline, 211.

15 Alois Riegl, Historische Grammatik der bildenden Künste (Graz and Köln: Hermann Böhlaus, 1966; posthumously published book manuscript of 1897-98 and lecture notes of 1899).

16 Although not quite so alongside but as an afterthought and just a little behind: 'From that foundation three main sections would arise: a central building for architecture and two secondary wings for sculpture and painting. But soon it became apparent that many works of art did not fit into these categories. A fourth section was therefore added, a back wing to stand behind architecture, and it was called industrial art. Then all four parts were raised with speed and vigor into the heights.' Alois Riegl, Historical Grammar of the Visual Arts (New York: Zone Books, 2004), 287. 17 Alois Riegl, Spätrömische Kunstindustrie nach den Funden in ÖsterreichUngarn (Vienna: Österreichische Staatsdruckerei, 1927; first published in 1901). He discussed only the decorative arts in his Stilfragen. Grundlegungen zu einer Geschichte der Ornamentik (Berlin: Georg Siemens, 1893), focusing on the development of ornament from prehistoric times to the Byzantine and early Islamic art. 18 Everyday objects make an occasional appearance here and there, incidentally or as a curiosity, merely confirming the general argument about the art in question, for example 
pointed gothic shoes (in Heinrich Wölfflin, "Prolegomena zu einer Psychologie der Architektur" (1886), Kleine Schriften (Basel: Schwabe, 1946),44-45) and a car radiator (in Erwin Panofsky, "The Ideological Antecedents of the Rolls-Royce Radiator," Proceedings of the American Philosophical Society 107, no. 4 (1963), 273-288). 19 See: Mark Crinson and Richard J. Williams, The Architecture of Art History. A Historiography (London: Bloomsbury Visual Arts, 2019). 20 Pevsner, Outline, xix.

21 Pevsner, Outline, 207, 209.

22 Pevsner's inclusion of design is usually explained away by biographical circumstances, by the fact that after his migration to England, in 1934-35, he was employed for a reasearch project on the state of English industrial design at the Department of Commerce at the University of Birmingham. However, that explains only the reason why Pevsner got well acquainted with the design at all, and does not an answer the question why he included it in a history about architecture. 23 Pevsner, Pioneers, 19, 20, 26, 177, 201; Pevsner, Enquiry, 9, 45, 187.

24 Pevsner, Pioneers, 204. Demonstrated as well in his change of the title from the pioneers of 'the Modern Movement' to those of 'modern design'. 25 Pevsner, Enquiry, 173; see also: 9, 187, 190.

26 Herbert Read, Art and Industry. The Principles of Industrial Design (London: Faber and Faber, 1934). About the book, see: Robin Kinross, "Herbert Read's Art and Industry: a history," Journal of Design History 1, no. 1 (1988), 35-50. 27 Pevsner, Enquiry, 190.

28 They were both art historians by profession and they both received first-hand experience of handicrafts or design at their jobs; Pevsner as a aforementioned reasearcher at Birmingham University and Read as an assistant keeper at the Department of Ceramics at Victoria and Albert Museum in London. 29 Read, Art and Industry, 1.

30 Read, Art and Industry, 1.

31 Read, Art and Industry, 3. Read, too, emphasises the contribution of the engineers in solving this problem and in developing a new aesthetic, inspiring 'more conscious architects and designers', 'a few pioneer spirits' to evolve a new tradition, based on practical realities; and he admits that he has 'no other desire in this book than to support and propagate the ideals' expressed by Gropius. Read, Art and Industry, 2, 40. 32 Read, Art and Industry, 33.

33 Read, Art and Industry, 35.

34 Read, Art and Industry, 38.

35 Pevsner, Enquiry, 187.

36 Pevsner, Outline, 211.

37 Pevsner, Pioneers, 22, 110.

38 Pevsner, Pioneers, 22-23.

39 Pevsner, Outline, 207.

40 Pevsner, Pioneers, 24, 26, 38.

41 Pevsner, Pioneers, 39.

42 Pevsner, Enquiry, 199.

43 Pevsner, Enquiry, 11. Pevsner's political views is a contentious issue. It was supposed that in his political attitude he was left-oriented, but then his early sympathies with the National Socialist movement were discovered and 
foregrounded. Pevsner never expressed a straightforward and unambiguous position as to 'the social question of our time', at least not publicly. Both Games and Harris emphasise Pevsner's basic indifference towards politics: he 'remained left-leaning in the narrow sense that he saw modern architecture as an expression of a society designed to meet the needs of all equally' (Susie Harries, Nikolaus Pevsner. The Life (London: Pimlico, 2013), 783), but he 'expressed no obvious interest in social politics, [...] he wanted better living conditions and a more intelligent aesthetic but no obvious change in the nature of society' (Stephen Games, Pevsner: The BBC Years. Listening to the Visual Arts (Farnham: Ashgate, 2015), 276). 44 Pevsner, Enquiry, 212, 213.

45 Pevsner, Sources, 7.

46 Pevsner, Enquiry, 201.

47 Pevsner, Enquiry, 202.

48 Pevsner, Sources, 9.

49 Pevsner, Outline, 214.

50 Pevsner, Outline, xix; Pevsner, Enquiry, 112.

51 Pevsner, Sources, 7, 8.

52 Pevsner, Sources, 201-202.

53 Pevsner, Enquiry, 83.

Received: 2020-05-31

Revised: 2020-06-24

Accepted: 2020-07-06 